\title{
PENGEMBANGAN MODUL FISIKA MULTIREPRESENTASI BERBASIS PROBLEM BASED LEARNING PADA MATERI DINAMIKA ROTASI DAN KESETIMBANGAN BENDA TEGAR UNTUK MENINGKATKAN KETERAMPILAN BERPIKIR KRITIS SISWA SMA KELAS XI
}

\author{
Ratih Astuti Handayani ${ }^{1}$, Sukarmin ${ }^{2}$, Sarwanto ${ }^{3}$ \\ ${ }^{1}$ Program Studi Magister Pendidikan Sains FKIP Universitas Sebelas Maret \\ Surakarta, 57126, Indonesia \\ ratihastuthandayani@gmail.com \\ ${ }^{2}$ Program Studi Magister Pendidikan Sains FKIP Universitas Sebelas Maret \\ Surakarta, 57126, Indonesia \\ sukarmin67@staff.uns.ac.id \\ ${ }^{3}$ Program Studi Magister Pendidikan Sains FKIP Universitas Sebelas Maret \\ Surakarta, 57126, Indonesia \\ sarwanto@fkip.uns.ac.id
}

\begin{abstract}
Abstrak
Hasil TIMSS menunjukkan kemampuan penalaran siswa Indonesia yang merupakan ciri berpikir kritis memiliki rata-rata paling rendah diantara domain pengetahuan dan penerapan. Penelitian ini bertujuan untuk mengetahui: (1) karakteristik modul fisika multirepresentasi berbasis PBL pada materi dinamika rotasi dan kesetimbangan benda tegar untuk meningkatkan keterampilan berpikir kritis; (2) kelayakan modul fisika multirepresentasi berbasis PBL pada materi dinamika rotasi dan kesetimbangan benda tegar; (3) efektivitas modul fisika multirepresentasi berbasis PBL untuk meningkatkan keterampilan berpikir kritis siswa. Metode penelitian ini adalah R\&D dengan model 4-D yang terdiri dari : (1) define (pendefinisian), (2) design (perancangan), (3) develop (pengembangan), (4) disseminate (penyebaran). Modul disusun dengan tahapan PBL yaitu merumuskan masalah, merumuskan hipotesis, mengumpulkan data, menguji hipotesis, dan merumuskan kesimpulan. Pengembangan modul meliputi proses validasi kelayakan modul, revisi modul, dan implementasi modul multirepresentasi berbasis PBL di kelas XI SMAN 3 Sukoharjo. Analisis data yang digunakan selama penelitian adalah analisis deskriptif berdasarkan skor kriteria dan analisis peningkatan keterampilan berpikir kritis siswa menggunakan nilai gain.. Hasil penelitian ini sebagai berikut: (1) karakteristik modul fisika yang dikembangkan memuat tahapan berbasis PBL pada setiap kegiatan belajar disertai dengan komponen indikator keterampilan berpikir kritis. Modul diengkapi dengan penyampaian konsep dalam representasi verbal, gambar, diagram bebas dan matematis; (2) modul dikategorikan layak berdasarkan ahli materi, ahli media, ahli bahasa, guru fisika, dan peer review yang ditunjukkan dengan nilai rata-rata 88,64 lebih besar dari nilai minum kelayakan 88,44 . Serta didukung dengan respon dari siswa dengan kategori baik dan hasil disseminate yang mengkategorikan modul sangat baik; (3) keterampilan berpikir kritis siswa setelah menggunakan modul fisika multirepresentasi berbasis PBL mengalami peningkatan dalam kategori sedang dengan $\mathrm{N}$ Gain sebesar 0,49.
\end{abstract}

Kata Kunci: modul fisika, multirepresentasi, problem based learning, keterampilan berpikir kritis

\section{Pendahuluan}

Salah satu tujuan dari suatu proses pembelajaran adalah terbentuknya peserta didik yang berkualitas baik. Kenyataan di lapangan sangat jauh berbeda, kualitas pendidikan di Indonesia saat ini cukup memprihatinkan. Berdasarkan hasil survei TIMSS (2011), rata-rata siswa menjawab benar pada ranah knowing (mengetahui) sebesar $36 \%$, menjawab benar ranah applying (menerapkan) sebesar $27 \%$, serta 
persentase menjawab benar ranah reasoning (penalaran) sebesar 20\%. Hasil riset TIMSS menunjukkan bahwa kemampuan sains Indonesia ditinjau dari domain kognitif menunjukkan bahwa kemampuan rata-rata siswa paling tinggi adalah pada domain pengetahuan (knowing), sedangkan kemampuan pada domain penalaran (reasoning) yang merupakan ciri berpikir tingkat tinggi relatif rendah. Hal ini mengindikasikan bahwa kemampuan sains siswa indonesia masih harus ditingkatkan pada semua aspek, terutama pada aspek penalaran (reasoning). Aspek penalaran belum optimal dilatihkan kepada siswa pada proses pembelajaran sains di Indonesia khususnya melatihkan siswa untuk menganalisis, memecahkan masalah, melakukan sintesis, membuat hipotesis, membuat rencana, merancang percobaan, merumuskan kesimpulan, membuat generalisasi, mengevaluasi dan mempertimbangkan (Nilam, 2016).

Keterampilan berpikir kritis dituntut dalam mempelajari materi eksak seperti fisika. Sehingga pembelajaran fisika dapat menjadi pendorong yang kuat tumbuhnya sikap rasa ingin tahu, keterbukaan terhadap ide-ide baru, dan dapat membantu siswa memahami pentingnya berpikir kritis dalam memecahkan masalah (Mundilarto, 2013). Pada kenyataannya pembelajaran fisika yang terjadi di sekolah umumnya siswa "malas berpikir" mereka cenderung menjawab suatu pertanyaan dengan cara mengutip dari buku atau bahan pustaka lain tanpa mengemukakan pendapat atau analisisnya terhadap pendapat tersebut sehingga lebih menekankan pada aspek kognitif dengan menggunakan hafalan dalam upaya menguasai ilmu pengetahuan bukan mengembangkan keterampilan berpikir (Lovy \& Gunawan, 2008).

Pembelajaran fisika dianggap susah dan rumit bagi siswa karena dalam penyajiannya sangat komplek (Suparno, 2009). Salah satu contohnya adalah siswa harus dapat mengubah dari bentuk penyajian grafik ke penyajian matematis, eksperimen, rumusan dan kalkulasi, grafik, dan penjelasan konseptual pada waktu yang sama (Ornek, 2008). Goldin (2002) menyatakan bahwa fisika menuntut siswa untuk menguasai representasi-representasi berbeda (grafik, konseptual, rumus, percobaan, gambar). Namun, ketidakmampuan siswa menggunakan multirepresentasi dalam memahami konsep fisika nampaknya telah menjadi halangan/batas pemahaman mereka. Siswa mengalami kesulitan karena strategi yang diajarkan dalam pembelajaran hanya untuk menyelesaikan masalah yang membutuhkan perhitungan matematis semata. Hal ini diperkuat oleh penelitian Sirait (2010) terhadap 73 orang siswa SMA di kota Pontianak menunjukkan bahwa $97 \%$ siswa menggunakan representasi persamaan matematika, $\quad 70 \%$ menggunakan representasi grafik, dan 30\% menggunakan representasi gambar dalam menyelesaikan soal fisika. Sejalan dengan Sirait, Alqadri (2011) menyatakan bahwa guru belum berperan aktif dalam pembelajaran menggunakan multirepresentasi. Guru sering menggunakan representasi matematika saja. Siswa yang terbiasa untuk menggunakan persamaan matematis saja, akan mengalami kesulitan untuk menguasai konsep dan menggunakannya untuk memecahkan masalah.

Materi dinamika rotasi dan kesetimbangan benda tegar merupakan materi fisika yang masih dianggap sulit, baik oleh siswa maupun guru. Daya serap pada materi tersebut tergolong rendah untuk lingkup kabupaten yaitu 64,36 lebih rendah bila dibandingkan dengan provinsi $(70,45)$ dan Nasional $(70,05)$. Materi ini tidak mudah untuk dipahami hanya dengan menghafal rumus. Sejalan dengan penelitian yang dilakukan Rosengrant (2009) menyatakan bahwa untuk memecahkan soal-soal dinamika dibutuhkan ketrampilan berpikir kritis siswa yaitu kemampuan siswa untuk menganalisis gaya-gaya yang bekerja pada suatu benda dan menggambarkannya dalam bentuk diagram benda bebas (free body 
diagrams). Oleh karena itu menurut Heuvalen (2001) pembelajaran fisika cocok diterapkan dengan multirepresentasi yang melibatkan penerjemahan secara berurutan dari masalah fisika yang diberikan dari satu simbol bahasa ke lainnya, dimulai dengan menulis deskripsi masalah secara verbal, kemudian dipindahkan ke bentuk gambar yang disesuaikan dan representasi diagram, dan diakhiri dengan rumus matematis yang dapat digunakan untuk menentukan jawaban menggunakan angka.

Salah satu penunjang

pembelajaran yang dapat membantu siswa dalam memahami materi adalah adanya bahan/media ajar. Berdasarkan hasil PISA Literasi membaca Indonesia berada pada peringkat ke 48 dari 56 negara (OECD, 2014). Rendahnya kemampuan membaca siswa dipengaruhi oleh beberapa faktor, misalnya kondisi bahan ajar. Seperti yang disarikan dari penelitian Pratama (2014) yang menyatakan bahwa kerumitan bahan ajar yang disampaikan semakin membuat siswa lemah dan malas dalam membaca pembelajaran.

Pengembangan bahan ajar menjadi bagian dari kompetensi yang harus dimiliki oleh guru. Peraturan Pemerintah nomor 19 tahun 2005 Pasal 20 mengisyaratkan guru untuk mampu mengembangkan materi pembelajaran. Selain mengembangkan materi pembelajaran, pendidik harus mampu mengembangkan bahan ajar untuk menyampaikan materi. Sejalan dengan hal tersebut Sungkono (2002) mengatakan bahwa "salah satu kompetensi yang perlu dimiliki seorang guru dalam melaksanakan tugasnya adalah mengembangkan bahan ajar". Menurut Prastowo (2015). Pengembangan bahan ajar penting dilakukan guru agar pembelajaran lebih efektif, efisien, dan sesuai dengan kompetensi yang ingin dicapai. Namun, guru pada umumnya lebih mengandalkan bahan ajar yang berasal dari penerbit, baik berupa buku ajar ataupun Lembar Kerja Siswa (LKS) dengan alasan membuat bahan ajar merupakan pekerjaan yang sulit dan membutuhkan waktu yang lama. Adanya sumber, bahan dan media yang baik dan tepat mampu meningkatkan kualitas pembelajaran. Bahan ajar yang kurang mampu menumbuhkan rasa cinta membaca dapat menimbulkan rasa tidak suka terhadap pelajaran Fisika. Rasa tidak suka ini akan berpengaruh pada keaktifan siswa dalam belajar dan berakibat pemahaman konsep fisika berkurang.

Pemahaman terhadap konsep fisika yang diajarkan mempengaruhi tingkat berpikir kritis siswa. Keterampilan berpikir kritis dapat diajarkan melalui sebuah pendidikan agar mampu menilai dengan akurat, dan berargumentasi dengan baik. Hal ini akan terlihat pada saat kegiatan pembelajaran berlangsung, diperlukan kegiatan pembelajaran yang aktif dan kondusif yang bertujuan agar pengembangan keterampilan berpikir siswa dapat berjalan dengan baik.

Pembelajaran fisika akan lebih bermakna dan dapat meningkatkan keterampilan berpikir siswa jika mampu tercipta kondisi pembelajaran yang membuat siswa terlibat secara aktif dan kreatif. Salah satu model pembelajaran yang dapat membantu siswa dan guru dalam proses pembelajaran fisika untuk meningkatkan keterampilan berpikir kritis adalah model pembelajaran berbasis masalah (PBL). Menurut Hamruni (2012) pada PBL peserta didik terlebih dahulu disajikan permasalahan fisis yang dapat siswa amati pada kehidupan sehari-hari dan selanjutnya peserta didik bertanggung jawab untuk menyelidiki masalah-masalah tersebut. Keterkaitan antara materi dan lingkungan mereka dapat menimbulkan kebermaknaan dalam pembelajaran sehingga dapat meningkatkan pemahaman dan penguasaan konsep siswa. Sesuai dengan penelitian yang dilakukan oleh Handayani (2016) menyatakan bahwa pembelajaran fisika dengan model pembelajaran Problem Based Learning dapat meningkatkan keterampilan berpikir kritis siswa. Penelitian Handayani diperkuat oleh Wina (2010) yang menyatakan bahwa 
pembelajaran berbasis masalah merupakan rangkaian aktivitas pembelajaran yang menekankan kepada proses penyelesaian masalah yang dihadapi secara ilmiah. Pengakomodasian kemampuan berpikir nalar dapat dilihat dari tahapan model PBL.

Sehubungan dengan penjelasan mengenai rendahnya minat baca dan ketrampilan berfikir kritis dalam pembelajaran fisika, dibutuhkan adanya pengembangan bahan ajar yang dapat meningkatkan ketrampilan berfikir kritis serta penyajiannya dikemas secara multirepresentasi. Modul dijadikan pilihan karena banyak kelebihan diantaranya: 1) sebagai sumber belajar yang dimiliki siswa sepenuhnya sehingga siswa dapat mempelajari modul kapanpun dan dimanapun yang ia kehendaki, 2) mengaktifkan indera penglihatan, pendengaran, dan gerakan siswa, 3) mengurangi pembelajaran yang berpusat pada guru, 4) modul memberikan feedback yang banyak dan segera karena pada modul terdapat kunci jawaban sehingga siswa dengan segera dapat mengetahui taraf hasil belajarnya.

Berdasarkan penjelasan latar belakang masalah, penelitian bertujuan untuk mengetahui: (1) karakteristik modul fisika multirepresentasi berbasis PBL pada dinamika rotasi dan kesetimbangan benda tegar untuk meningkatkan keterampilan berpikir kritis siswa; (2) kelayakan terhadap modul fisika multirepresentasi berbasis PBL; (3) efektivitas modul fisika multirepresentasi berbasis PBL dapat meningkatkan keterampilan berpikir kritis siswa.

\section{Metode Penelitian}

\begin{tabular}{ccc}
\multicolumn{1}{c}{ Metode } & penelitian & yang \\
digunakan adalah & penelitian & dan \\
pengembangan & (research & and
\end{tabular} development). Penelitian pengembangan adalah metode penelitian yang digunakan untuk menghasilkan produk tertentu dan menguji keefektifan produk tersebut (Sugiyono, 2012). Model yang digunakan sebagai dasar untuk mengembangkan modul fisika multirepresentasi berbasis PBL merupakan hasil adaptasi model 4-D (four-D model) yang dikemukakan oleh Thiagarajan (1974). Tahap penelitian meliputi proses define, design, develop, dan disseminate.

Penelitian dilaksanakan pada siswa kelas XI SMAN 3 Sukoharjo tahun ajaran 2015/2016 dengan materi yang digunakan adalah dinamika rotasi dan kesetimbangan benda tegar. Desain penelitian yang digunakan adalah one group pretest and posttest, sehingga penelitian hanya melibatkan sekelompok subjek yang diberi pre-test sebelum dikenai perlakuan, dan post-test setelah dikenai perlakuan untuk diketahui hasil akibat perlakuan tersebut.

Instrumen pengumpulan data yang digunakan dalam penelitian ini adalah: (1) instrumen observasi yang meliputi lembar observasi hasil belajar dari aspek afektif, dan lembar observasi hasil belajar dari aspek psikomotorik; (2) angket yang meliputi angket kebutuhan siswa, angket analisis kebutuhan guru, dan angket penilaian produk; (3) lembar validasi materi, media dan bahasa, praktisi dan teman sejawat; (4) tes yang meliputi tes keterampilan berpikir kritis dan penilaian aspek kognitif. Instrumen-instrumen yang digunakan sudah melalui validasi oleh pembimbing.

Data yang diperoleh pada penelitian pengembangan modul fisika multirepresentasi berbasis PBL untuk siswa SMA/MA kelas XI adalah data analisis kebutuhan siswa, data analisis kebutuhan guru, data validasi modul oleh validator ahli (materi, bahasa dan media), guru fisika dan teman sejawat, data nilai afektif, kognitif, psikomotorik, data peningkatan keterampilan berpikir kritis dan data penilaian produk oleh siswa. Data yang diperoleh dari analisis kebutuhan siswa dan analisis kebutuhan guru ditabulasi dan dikonversi menjadi bentuk persentase. Hasil validasi modul, nilai afektif, nilai psikomotorik dan hasil penilaian produk ditabulasi kemudian dilakukan analisis 
deskriptif terhadap hasilnya. Hasil penilaian kognitif dianalisis dengan membuat ratarata nilai kemudian dibandingkan dengan kriteria ketuntasan minimal mata pelajaran fisika, sedangkan hasil pretest dan posttest dari tes keterampilan berpikir kritis dianalisis dengan n-gain ternormalisasi (Meltzer, 2001). Menurut Syaifudin (2011) indikator keberhasilan penelitian dan pengembangan ini adalah peningkatan perolehan gain hasil analisis skor sebelum dan setelah kegiatan pembelajaran sekurang-kurangnya dalam kategori sedang.

\section{Hasil Penelitian dan Pembahasan}

Model yang digunakan sebagai dasar untuk mengembangkan modul fisika multirepresentasi berbasis PBL ini merupakan hasil adapatasi model 4-D (four$D$ model) yang dikemukakan oleh Thiagarajan (1974) yang meliputi proses define, design, develop, dan disseminate yang menunjukkan hasil sebagai berikut :

\section{A. Tahap Define}

Tahap ini merupakan tahapan untuk mengidentifikasi masalah-masalah yang ada dalam proses pembelajaran dan menjadi dasar untuk merancang produk berupa modul yang dibuat. Pada tahapan ini dilakukan analisis kebutuhan siswa, analisis kebutuhan guru dan analisis materi pembelajaran. Analisis kebutuhan siswa dilakukan pada 33 siswa kelas XI IPA dan analisis kebutuhan guru dilakukan pada 4 orang guru fisika di SMAN 3 Sukoharjo. Berdasarkan data angket kebutuhan guru sebesar $75 \%$ guru menggunakan buku yang sama dengan buku siswa, $75 \%$ guru merasa adanya keterbatasan dari buku ajar dari segi materi dan teknik penjelasan kurang mendalam. Guru membutuhkan bahan ajar seperti modul yang mempunyai gambar/ilustrasi yang menarik dan berwarna. Selanjutnya guru juga membutuhkan modul yang dapat menjelaskan materi secara jelas dan lengkap dengan bahasa yang mudah dipahami oleh siswa dengan representasi yang berbeda. 50\% guru menyatakan bahwa tidak semua buku ada lembar kerja siswa yang mengandu percobaan. Sebanyak 96\% guru menginginkan modul yang mampu melatih keterampilan berpikir tingkat tinggi siswa melalui pembelajaran PBL. Berdasarkan angket kebutuhan siswa $100 \%$ siswa hanya menggunakan buku dari penerbit, 59\% siswa mengatakan bahwa buku dari penerbit kurang menarik karena kurang jelas, tidak ada penurunan rumus, kurang gambar dan contoh soal sedikit. Siswa membutuhkan bahan ajar yang memuat narasi, gambar dan persamaan yang memperjelas konsep serta menarik penyajiannya. $75 \%$ siswa memilih modul yang memuat karakteristik PBL seperti adanya masalah diawal pembelajaran, kolaboratif, kooperatif dan dapat menyatakan pendapatnya.

Berdasarkan analisis kurikuluum, materi yang dipilih adalah materi dinamika rotasi dan kesetimbangan benda tegar. Kemampuan yang diuji adalah menentukan besaran-besaran fisis dinamika rotasi (torsi, momentum sudut, momen inersia, dan titik berat) dan penerapannya berdasarkan hukum II Newton dalam masalah benda tegar. Daya serap nilai yang diperoleh SMA di kabupaten Sukoharjo yaitu 64,36 lebih rendah bila dibandingakn dengan provinsi $(70,45)$ dan Nasional $(70,05)$. Hal ini bertujuan sesuai dengan penelitian Tze Kiong (2011) bahwa penggunaan modul dapat menjadi alternatif dalam pemecahan masalah belajar siswa.

\section{B. Tahap Design}

Pada tahapan ini dilakukan perancangan draf modul yang akan dikembangkan. Bagian-bagian modul yang akan dikembangkan meliputi identitas modul, kata pengantar, bagian modul, petunjuk penggunaan modul, peta konsep, pengantar modul, kegiatan belajar, uraian materi, contoh soal, info teknologi, evaluasi, refleksi, uji kompetensi, kunci jawaban, glosarium, dam daftar pustaka Modul ini akan dikembangkan berdasarkan sintaks PBL menurut John Dawey cit. Hamruni (2012) yang terdiri dari merumuskan masalah, merumuskan 
hipotesis, mengumpulkan data, menguji hipotesis dan merumuskan rekomendasi pemecahan masalah. Keterampilan berpikir kritis yang diukur sesuai dengan teori Facione (1990) yaitu meliputi interpretasi (interpretation), analisis (analisys), evaluasi (evaluation), kesimpulan (inference), penjelasan (explanation), dan pengaturan diri (self-regulation).

Modul terdiri dari tiga kegiatan belajar, KB.1 berisikan materi torsi dan inersia, KB.2 berisikan materi energy kinetic rotasi dan momentm sudut, dan KB.3 berisikan materi kesetimbangan benda tegar dan titik berat. Penyajian tiap sub pokok bahasan dalam bentuk atau representasi gambar/foto, diagram bebas, verbal, dan matematis. Mempelajari konsep dinamika rotasi dan kesetimbangan benda tegar cocok menggunakan multirepresentasi karena menurut Hinrich (2007) menguraikan bahwa Multirepresentasi dapat membantu siswa dalam memahami suatu materi dinamika.

Sintaks PBL pada desain modul berbasis PBL ini dikemas dalam rubrik yaitu: (1) sintaks merumuskan masalah terintegrasi dalam rubrik "Peristiwa" untuk meningkatkan keterampilan berpikir kritis interpretasi dan "Mari Merumuskan" untuk meningkatkan keterampilan berpikir kritis analisis (analysis); (2) sintaks menguji hipotesis dalam rubrik "Hipotesismu" untuk meningkatkan keterampilan berpikir kritis inference; (3) sintaks mengumpulkan data terintegrasi dalam rubrik "Mari Mencoba" untuk meningkatkan keterampilan berpikir kritis analisis dan inference; (4) sintaks menguji hipotesis terintegrasi dalam rubrik "Ujilah hipotesismu" untuk meningkatkan keterampilan berpikir kritis inference, evaluasi dan penjelasan dan (5) sintaks merekomendasikan pemecahan masalah hasil terintegrasi dalam rubrik "Kesimpulanmu" untuk meningkatkan keterampilan berpikir kritis inference dan regulasi diri. Modul yang sudah jadi kemudian divalidasi dan direvisi sesuai dengan tahap selanjutnya yaitu tahap pengembangan (develop) dalam proses penelitian.

\section{Tahap Develop}

Tahapan Develop ini diawali dengan validasi draf I modul fisika multirepresentasi berbasis PBL yang dilakukan oleh validator ahli, guru fisika dan teman sejawat yang selanjutnya direvisi kemudian dujicobakan ke kelompok kecil dan di implementesaikan pada kelompok besar.

1. Hasil Validasi Modul

Validasi dilakukan oleh tiga validator ahli, dua guru fisika dan dua teman sejawat. Validasi dilakukan menggunakan lembar validasi yang mengadaptasi lembar validasi buku teks pelajaran dari BSNP sesuai kebutuhan peneliti. Validasi modul menitikberatkan pada komponen kelayakan isi dan penyajian, bahasa, dan kelayakan kegrafisan. Tiga validator ahli memvalidasi modul yang telah dibuat dengan menilai aspek penyajian materi, aspek kebahasaan, dan aspek media yang berupa tampilan dan gambar. Dua guru fisika dan dua teman sejawat juga menilai aspek materi, bahasa dan media. Diagram batang hasil validasi modul fisika multirepresentasi berbasis PBL yang dikembangkan peneliti diperlihatkan dalam Gambar 1.

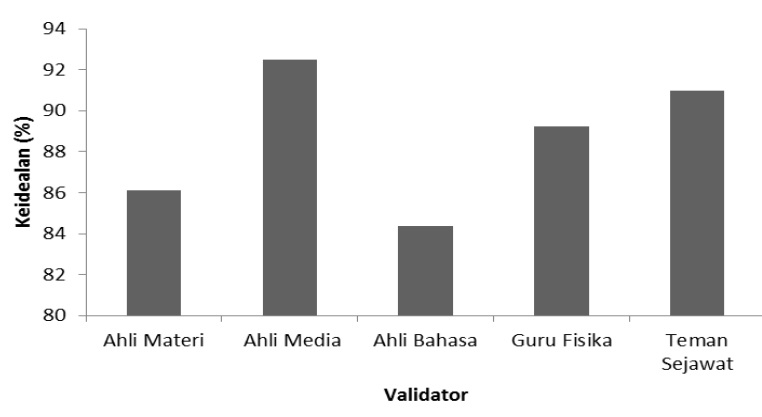

Gambar 1. Hasil validasi Modul

Hasil validasi yang ditunjukkan Gambar 1 memperlihatkan bahwa modul fisika multirepresetasi berbasis PBL yang mendapatkan nilai secara keseluruhan mendapatkan prosentase keidealan 88,64\% tergolong kategori "Sangat baik". Nilai ini berarti bahwa modul yang dikembangkan sangat baik dari segi isi dan penyajian, 
kebahasaan, penyajian dan kegrafikan sehingga sangat layak digunakan dalam pembelajaran. Hal ini juga sesuai dengan hasil perhitungan dengan metode metode cut off (Winnie, 2009). Nilai yang dihasilkan dari analisis cut off adalah 88,44 dan nilai rata-rata penilaian modul adalah 88,64 . Hal ini menunjukkan bahwa ratarata penilaian lebih besar dibandingkan nilai analisis cut off, sehingga dapat disimpulkan bahwa modul tersebut layak untuk digunakan dalam pembelajaran. Menurut Winarno (2014) hasil respon guru pada kategori sangat baik menunjukkan bahwa modul dikategorikan layak untuk digunakan sebagai salah satu media pembelajaran. Didukung dengan penelitian Prapti (2013) yang menyatakan sebelum digunakan dalam proses pembelajaran hendaknya perangkat pembelajaran mempunyai status valid dengan kriteria penilaian minimal baik.

\section{Revisi I}

Setelah validasi dilakukan, draf I kemudian direvisi berdasarkan saran/ masukan dari validator seperti ditampilkan dalam Tabel 1.

Tabel 1. Hasil Revisi Modul dari Validator

\begin{tabular}{|c|c|}
\hline Sebelum Revisi & Setelah Revisi \\
\hline $\begin{array}{l}\text { Rumus tidak perlu dimasukkan } \\
\text { dalam peta konsep }\end{array}$ & Sudah dihapus \\
\hline $\begin{array}{l}\text { Pada peristiwa } 5 \text { permasalahan } \\
\text { diganti dengan seseorang yang } \\
\text { sakit punggung akibat } \\
\text { membawa tas berat }\end{array}$ & $\begin{array}{l}\text { Pada peristiwa } 5 \\
\text { permasalahan yang } \\
\text { semula permainan } \\
\text { judo diganti dengan } \\
\text { punggung yang sakit } \\
\text { ketika keseringan } \\
\text { membawa tas berat }\end{array}$ \\
\hline $\begin{array}{l}\text { Pada hal } 9 \text { gambar dan } \\
\text { persamaan tidak sesuai }\end{array}$ & $\begin{array}{l}\text { Persamaan sudah } \\
\text { diganti } \\
\text { menyesuaikan } \\
\text { gambar yaitu semula } \\
\text { Fxr menjadi } \\
r x F\end{array}$ \\
\hline $\begin{array}{l}\text { Bebarapa representasi gambar } \\
\text { dan diagram perlu diperjelas }\end{array}$ & $\begin{array}{l}\text { Gambar dan diagram } \\
\text { yang kurang jelas } \\
\text { sudah diganti }\end{array}$ \\
\hline $\begin{array}{l}\text { Pada pembahasan energi } \\
\text { kinetik ditambahi penjelasan } \\
\text { kasus benda menggelinding } \\
\text { dari ketinggian } h \text { menurut } \\
\text { inersia benda yang beragam }\end{array}$ & $\begin{array}{l}\text { Penjelasan sudah } \\
\text { ditambahi }\end{array}$ \\
\hline Gunakan huruf yang luwes & $\begin{array}{l}\text { Huruf Times New } \\
\text { Roman sudah diganti } \\
\text { menjadi Bookman } \\
\text { Old Style }\end{array}$ \\
\hline $\begin{array}{l}\text { Warna background dengan } \\
\text { tulisan harus kontras }\end{array}$ & $\begin{array}{l}\text { Warna background } \\
\text { sudah dikontraskan } \\
\text { dengan warna tulisan }\end{array}$ \\
\hline
\end{tabular}

\begin{tabular}{llr}
\hline $\begin{array}{l}\text { Penggunaan kata depan masih } \\
\text { perlu diteliti lagi }\end{array}$ & $\begin{array}{l}\text { Penggunaan kata } \\
\text { depan sudah direvisi }\end{array}$ \\
\hline $\begin{array}{l}\text { Penulisan persamaan } \\
\text { menggunakan equation }\end{array}$ & $\begin{array}{l}\text { Semua penulisan } \\
\text { persamaan } \\
\text { direvisi } \\
\text { menggunakan }\end{array}$ \\
& $\begin{array}{l}\text { eqution } \\
\text { Penulisan istilah asing dicetak }\end{array}$ & $\begin{array}{l}\text { Penulisan istilah } \\
\text { asing sudah dicetak }\end{array}$ \\
miring & $\begin{array}{l}\text { miring } \\
\text { Ada beberapa gambar yang } \\
\text { kurang jelas }\end{array}$ & $\begin{array}{l}\text { gambar yang kurang } \\
\text { jelas sudah diganti }\end{array}$ \\
\hline
\end{tabular}

Berdasarkan Tabel 1. menunjukkan hasil validasi yang belum direvisi dan telah direvisi. Perbaikan yang dilakukan antara lain : (1) rumus pada peta konsep sudah dihilangkan. Perbaikan tersebut mengacu pada Novak (1985) bahwa peta konsep digunakan untuk menyatakan hubungan yang bermakna antara konsep-konsep dalam bentuk proposisi-proposisi. Rumus bukan merupakan konsep sehingga lebih baik dihilangkan. (2) Font yang digunakan modul diganti dengan font yang lebih luwes. Perbaikan pada format penulisan dalam modul yang dilakukan dengan mengacu pada jurnal Paulinan (2001) mengenai elemen mutu pada penyusunan modul yang menjelaskan bahwa pada penulisan modul bentuk dan ukuran huruf dipilih yang mudah dibaca, luwes, tidak memuat lelah mata siswa. (3) kekontrasan background sudah diperbaiki. Menurut Paulinan, daya tarik modul dilihat salah satunya dari kemenarikan warna. kekontrasan warna antara background dengan tulisan sangat penting untuk memudahkan tulisan terbaca oleh pembaca. (4) gambar yang kurang jelas sudah diperjelas. Menurut Prastowo (2015) "gambar-gambar yang dapat mendukung dan memperjelas isi materi sangat dibutuhkan untuk menambah daya tarik dan mengurangi kebosanan peserta didik untuk mempelajarinya". (5) Selanjutnya perbaikan mengenai tanda baca, kata asing yang sesuai kaidah bahasa Indonesia. (6) materi sudah ditambahkan tentang kasus benda menggelinding pada ketinggian $h$ dengan inersia yang berbeda-beda. Prastowo (2015) yang menyatakan bahwa "uraian materi dijabarkan dan dijelaskan ke bagian-bagian 
yang lebih rinci dan mendetail agar pembaca bisa memahaminya secara mendalam".

Setelah draf I direvisi dihasilkan modul draf II yang terbentuk karena adanya masukan dan saran dari validator. Kemudian draf II siap diujicobakan terbatas.

\section{Uji Coba Terbatas}

Tahapan uji coba terbatas ini dilakukan pada 15 orang siswa kelas XI IPA 4 di SMAN 3 Sukoharjo. setelah mendapatkan produk yaitu modul cetak fisika multirepresetasi berbasis PBL pada dinamika rotasi yang sudah divalidasi oleh validator. Modul yang dikerjakan siswa diteliti dan dikoreksi sehingga dapat diketahui yang tidak dapat dipahami oleh siswa untuk saran perbaikan. Selain itu dilakukan penilaian angket keterbacaan, hasil angket ditabulasi dan dihitung sehingga diperoleh rata-rata 89,49 sehingga modul ini termasuk dalam kriteria 'sangat baik'. Nilai tersebut mengartikan bahwa menurut modul fisika multirepresentasi berbasis PBL pada materi dinamika rotasi dan kesetimbangan benda tegar yang dikembangkan sangat baik dalam segi isi/materi, sangat baik dalam segi kebahasaannya dan sangat baik juga dalam segi gambar dan penyajiannya.

4. Revisi II

Hasil dari ujicoba terbatas juga berupa saran dan masukan dari siswa yang diperbaiki oleh peneliti, diantaranya perbaikan terhadap redaksi pertanyaan dalam kegiatan analisis sehingga diubah karena siswa SMA sudah dapat membuat kalimat dan terdapat beberapa penulisan serta gambar yang kurang jelas. Setelah direvisi, hasil perbaikan kemudian disusun kembali menjadi draf modul III yang merupakan produk modul cetak yang siap digunakan untuk tahapan selanjutnya yaitu uji coba skala besar. Uji coba skala besar akan dilakukan pada siswa kelas XI IPA 2 SMAN 3 Sukoharjo yang berjumlah 30 siswa.

5. Uji Coba Lapangan Utama
Data yang didapatkan dalam uji coba lapangan dengan penerapan pembelajaran menggunakan modul fisika multirepresentasi berbasis PBL pada materi dinamika rotasi dan kesetimbangan benda tegar ini meliputi data hasil penilaian afektif, kognitif, psikomotorik dan data keterampilan berpikir kritis. Selain hal tersebut, siswa juga diminta untuk melakukan penilaian respon terkait penggunaan modul.

a. Penilaian Hasil Belajar

1) Aspek Afektif

Penilaian aspek afektif pada penelitian ini mencakup rasa ingin tahu, teliti dan bekerjasama dalam kelompok. Penilaian afektif dilakukan dengan cara observasi yang dibantu oleh observer I dan observer II dalam penilaiannya dengan lembar observasi afektif. Hasil penilaian afektif menunjukkan bahwa secara keseluruhan siswa kelas XI IPA 2 SMAN 3 Sukoharjo memiliki sikap dengan kategori baik dengan rata-rata penilaian keseluruhan aspek pada setiap pertemuan yaitu 78,48 . Aspek afektif yang paling terlihat dalam pembelajaran adalah rasa ingin tahu. Siswa terdorong keingintahuannya untuk menemukan konsep dan hasilnya dapat diaplikasikan dalam kehidupan sehari-hari. Sejalan dengan Desi (2016) Pada pembelajaran menggunakan PBL permasalahan muncul karena siswa aktif mencari masalah yang nyata dan yang mereka temukan, maka siswa akan sangat antusias untuk menyelesaikan masalah yang mereka temukan sendiri dengan rasa keingintahuan yang mereka miliki. Prapti (2013) mengungkapkan bahwa PBL akan membantu siswa mengembangkan kemampuan ranah afektif selain rasa ingin tahu dan tanggung jawab yaitu siswa akan saling kerjasama mencari informasi.

2) Aspek Kognitif

Penilaian aspek kognitif dilakukan pada saat akhir pembelajaran menggunakan modul fisika multirepresentasi berbasis PBL. Penilaian aspek kognitif dilakukan dengan tes hasil belajar kognitif berupa 20 soal pilihan 
ganda yang sebelumnya telah divalidasi pembimbing dan diujicobakan. Adapun hasil nilai kognitif siswa setelah menggunakan modul adalah sebagai berikut.

Tabel 2. Hasil Penilaian Kognitif

\begin{tabular}{lllll}
\hline $\begin{array}{l}\text { Jenis } \\
\text { Tes }\end{array}$ & $\begin{array}{l}\text { Jumlah } \\
\text { Siswa }\end{array}$ & Mean & $\begin{array}{l}\text { Nilai } \\
\text { Minimum }\end{array}$ & $\begin{array}{l}\text { Nilai } \\
\text { Maksimum }\end{array}$ \\
\hline Posttest & 30 & 78,17 & 65 & 90
\end{tabular}

Hasil penilaian menunjukkan nilai rata-rata keseluruhan siswa atau rata-rata kelas adalah 78,17, nilai tesebut melebihi nilai kriteria ketuntasan minimal (KKM) pelajaran fisika yang bernilai 75 . Hasil akhir menunjukkan bahwa $80 \%$ siswa tuntas KKM. Hasil tersebut sesuai penelitian Yuvita (2012) yang menunjukan bahwa hasil belajar anak pada materi kesetimbangan benda tegar meningkat setelah menggunakan modul multirepresentasi, sebanyak $80 \%$ siswa memenuhi KKM. Selain itu penelitian Selcuk (2013) dan Prapti (2013) juga menyatakan bahwa model pembelajaran berbasis masalah berpengaruh baik terhadap prestasi belajar pada mata pelajaran fisika.

3) Aspek Psikomotorik

Penilaian aspek psikomotorik siswa dalam penelitian berdasarkan lembar observasi aspek psikomotorik. Penilaian dilakukan pada setiap kelompok. Aspek penilaian yang dinilai pada aspek psikomotorik siswa adalah melakukan percobaan, membaca data hasil percobaan, dan menyusun laporan dalam modul. Hasil perhitungan analisis data diperoleh hasil bahwa nilai rata-rata psikomotorik siswa dalam setiap pertemuan mengalami peningkatan selalu melebihi nilai KKM (75). Nilai rata-rata psikomotorik dari semua aspek yang diteliti selama empat kali pertemuan adalah 79,04. Aspek psikomotorik yang paling tinggi rataratanya adalah aspek melakukan percobaan. Siswa cenderung mengalami peningkatan dalam melakukan percobaan dari menyiapkan alat dan bahan, kemudian membuat skema, lalu merangkai alat dan bahan dan mencobanya. Jadi, implementasi modul fisika berbasis masalah dalam pencapaian KKM ranah psikomotorik teruji efektivitasnya. Hasil tersebut sesuai dengan Mulyasa (2007) yang berpendapat bahwa proses pembentukan kompetensi dari segi proses dapat dikatakan berhasil apabila terjadi perubahan perilaku (75\%) sesuai dengan kompetensi dasar. Menurut Samsiah Mat et al (2012) pembelajaran menggunakan pendekatan pembelajaran berbasis masalah sangat efektif digunakan untuk mengembangkan kemampuan kerja tim. Etherington (2011) juga mengungkapkan pembelajaran berbasis masalah dinyatakan berhasil membuat nilai rata-rata aspek psikomotorik mengalami peningkatan karena siswa terlibat aktif dan lebih terarah saat eksperimen.

b. Penilaian Keterampilan Berpikir Kritis

Keterampilan berpikir kritis dalam penelitian ini dilakukan melalui pretest dan postest. Penilaian dilakukan dengan pretest dan postest sebelum dan sesudah pembelajaran menggunakan modul fisika multirepresentasi berbasis PBL. Soal keterampilan berpikir kritis terdiri dari 11 soal uraian terpilih setelah dilakukan analisis butir soal dari 14 item. Pengambilan data menggunakan 11 item soal tersebut sudah mewakili selurus aspek keterampilan berpikir kritis yang dinilai dalam pembelajaran. Berdasarkan hasil penelitian, gain setiap aspek keterampilan berpikir kritis ditabulasi dalam tabel 3 .

Tabel 3. N-Gain Setiap Aspek Keterampilan berpikir kritis

\begin{tabular}{clll}
\hline No. & Aspek & N-Gain & Kategori \\
\hline 1. & Interpretasi & 0,65 & Sedang \\
2. & Analisis & 0,38 & Sedang \\
3. & Evaluasi & 0,39 & Sedang \\
4. & Inference & 0,68 & Sedang \\
5. & Penjelasan & 0,48 & Sedang \\
6. & Regulasi diri & 0,59 & Sedang \\
\hline & Rata-rata & 0,49 & Sedang \\
\hline
\end{tabular}

Peningkatan skor masing-masing aspek digambarkan dalam bentuk diagram batang sebagai berikut. 


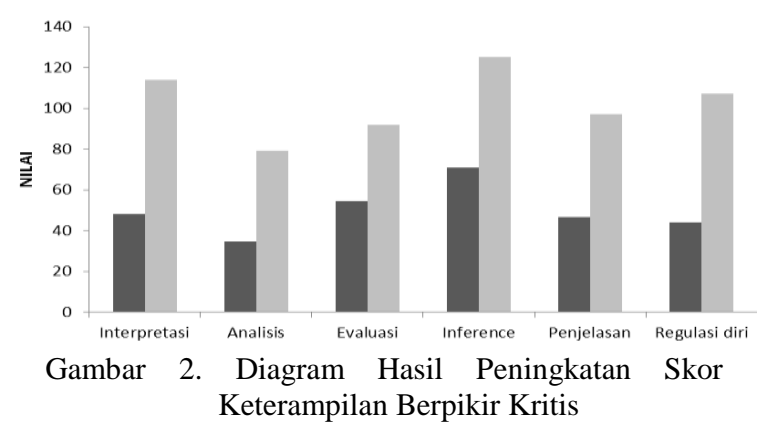

Berdasarkan Gambar 2 dan Tabel 3 dapat disimpulkan bahwa dengan modul fisika multirepresentasi berbasis PBL dapat membuat siswa mempunyai keterampilan interpretasi, analisis, inferensi, evaluasi, penjelasan dan regulasi diri dengan baik. Hasil ini sesuai dengan penelitian Trianto (2009) menyatakan bahwa pengajaran berdasarkan masalah merupakan pendekatan yang efektif untuk pengajaran proses berpikir tingkat tinggi termasuk didalamnya keterampulan berpikir kritis. Indikator kemampuan berpikir kritis yang mengalami peningkatan paling tinggi adalah kemampuan menyimpulkan. Kemampuan ini terukur pada kegiatan membuat kesimpulan berdasarkan data yang diperoleh dari suatu percobaan. Kegiatan percobaan pada model PBL bertujuan agar siswa dapat mengetahui penyelesaian masalah yang ditemui dalam kehidupan sehari-hari, sehingga diharapkan siswa dapat lebih mudah memahami suatu konsep. Hal ini sejalan dengan hasil penelitian Handayani, et al. (2016) yaitu pengalaman belajar akan membuat siswa lebih mudah mengingat apa yang mereka pelajari. Penggunaan multirepresentasi juga dapat meningkatkan keterampilan berpikir kritis siswa karena siswa dituntut untuk menganalisis suatu masalah yang terdiri dari representasi verbal/bahasa kemudian siswa menginterpretasikanya ke dalam sebuah gambar atau diagram dan kemudian dievaluasi dengan menggunakan persamaan matematis. Didukung dengan penelitian I Putu Wisma (2014) yang menyatakan bahwa penggunaan Lembar kerja multirepresentasi dapat meningkatkan keterampilan berpikir kritis karena siswa berlatih menemukan hubungan logis dari suatu masalah kemudian diterjemahkan kedalam representasi visual yang dapat membantu menyelesaikan masalah.

c. Respon Siswa Terhadap Modul

Respon terhadap modul dilakukan setelah pembelajaran menggunakan modul fisika multirepresentasi berbasis PBL. Penilaian dalam bentuk angket respon siswa. Penilaian dilakukan pada 30 responden. Penilaian secara keseluruhan terhadap modul diperoleh rata-rata keidealan 77,5\% yang masuk kategori baik. Hal ini menandakan bahwa modul fisika multirepresentasi tersebut baik digunakan sebagai salah satu bahan ajar/media ajar dalam pembelajaran sehingga dapat menjadi alternatif peningkatan hasil belajar. 6. Penyempurnaan (Revisi III)

Berdasarkan hasil uji skala besar menunjukkan bahwa modul sudah baik sehingga sudah layak ke tahap selanjutnya adalah tahap penyempurnaan modul. Tidak banyak hal yang dikukan dalam revisi penyempurnaan modul. Revisi hanya dilakukan pada perbaikan kata yang salah ketik. Selanjutnya modul yang telah direvisi pada tahap penyempurnaan siap untuk menuju tahap selanjutnya yaitu tahap penyebaran atau disseminate.

\section{Tahap Disseminate}

Pada tahapan penyebaran, modul fisika multirepresentasi berbasis PBL pada materi dinamika rotasi dan kesetimbangan benda tegar untuk kelas XI SMA/MA disebarkan di 5 sekolah di daerah Sukoharjo. Penyebaran dilakukan pada guru fisika di SMAN 1 Bulu, SMAN 1 Mojolaban, SMAN 1 Polokarto, SMA Muh Imam Syuhodo dan SMA Muh 1 Sukoharjo. Setelah diberikan modul fisika multirepresentasi berbasis PBL pada materi dinamika rotasi dan kesetimbangan benda tegar, guru-guru memberikan penilaian terhadap produk dengan mengisi angket. Rata-rata skor penialain 26,6 dari skor maksimal 32. Modul tergolong dalam kategori baik dengan persentase keidealan $83,13 \%$. Hal ini menunjukkan bahwa modul fisika multirepresentasi berbasis PBL yang sedang dikembangkan layak dipergunakan 
pada pembelajaran Fisika di SMA/ MA. Senada dengan penelitian Wiyadi (2014) yang menyatakan bahwa modul berbasis masalah layak digunakan sebagai sumber belajar bagi siswa dan mengakibatkan terjadi peningkatan prestasi siswa. Hal tersebut didukung oleh penelitian Sampurno (2009) dan Winarno (2014) jika hasil respon guru pada kategori "Sangat Baik" menunjukkan bahwa modul layak untuk digunakan sebagai salah satu media pembelajaran.

\section{Kesimpulan dan Rekomendasi}

\section{Kesimpulan}

Kesimpulan dari hasil penelitian pengembangan modul fisika multirepresetasi berbasis PBL pada materi dinamika rotasi dan kesetimbangan benda tegar untuk kelas XI SMA/MA yang telah dilakukan adalah:

1. Karakteristik khusus pengembangan modul fisika multirepresetasi berbasis PBL yang dikembangkan oleh peneliti dengan sintaks-sintaks pembelajaran PBL yang dituangkan pada rubrik dalam modul yaitu (1) sintaks merumuskan masalah terintegrasi dalam rubrik "Peristiwa" dan "Mari Merumuskan", (2) sintaks menguji hipotesis dalam rubrik "Hipotesismu", (3) sintaks mengumpulkan data terintegrasi dalam rubrik "Mari Mencoba", (4) sintaks menguji hipotesis terintegrasi dalam rubrik "Ujilah hipotesismu", (5) sintaks merekomendasikan pemecahan masalah hasil terintegrasi dalam rubrik "Kesimpulanmu" Karakteristik dari modul fisika ini selain menggunakan prosedur PBL adalah multirepresentasi. Representasi yang digunakan dalam modul fisika berbasis PBL telah dibatasi yaitu representasi verbal, matematis, diagram bebas, dan gambar.

2. Modul fisika multirepresentasi berbasis PBL pada materi dinamika rotasi dan kesetimbangan benda Tegar divalidasi oleh validator ahli materi, ahli media, ahli bahasa, guru fisika, dan teman sejawat. Hasil rata-rata dari uji kelayakan adalah $88,64 \%$ tergolong kategori "Sangat baik". Serta didukung respon dari siswa dengan kategori baik dan disseminate yang mengkategorikan modul sangat baik. Hasil tersebut menunjukkan bahwa modul layak digunakan dalam pembelajaran.

3. Pembelajaran dengan menggunakan modul fisika multirepresentasi berbasis PBL dapat meningkatkan keterampilan berpikir kritis siswa dengan gain ternormalisasi diperoleh nilai 0,49 dengan kategori sedang.

\section{Rekomendasi}

Dalam penggunaan modul fisika multirepresentasi berbasis PBL perlu diperhatikan beberapa hal diantaranya: (1) Perlu adanya persiapan yang baik dalam pembelajaran menggunakan modul fisika multirepresentasi berbasis PBL agar proses pembelajaran dapat berlangsung dengan baik sesuai dengan RPP yang telah dipersiapkan; (2) Multirepresentasi yang dikembangkan memiliki kesepadanan pada setiap kegiatan belajar; (3) Hasil penelitian ini dapat digunakan sebagai acuan untuk mengembangkan pengembangan modul dengan pendekatan pembelajaran dan materi yang berbeda.

\section{Daftar Pustaka}

Alqadri, S. (2011). Implementasi Penggunaan Multirepresentasi Guru Fisika SMA Pontianak Dalam Pembelajaran (Studi Kasus Pada Materi Hukum Newton di SMA Negeri 7 dan SMA Negeri 6 Pontianak). Pontianak: FKIP UNTAN (Skripsi)

Amir, M. T. (2009). Inovasi Pendidikan Melalui Problem Based Learning : Bagaimana Pendidik Memberdayakan Pemelajar Di Era Pengetahuan. Jakarta: Kencana Prenada Media Group.

Desi, Handayani. (2016). Penagruh PBL Terhadap Hasil Belajar IPA Siswa Kelas VIII SMP N 1 Teras Boyolali Semester Genap Tahun Ajaran 2015/2016. (Publikasi Ilmiah)

Etherington, Mattew et al. 2011. Investigative Primary Science: A Problem-based 
Learning Appoarch. Australian Journal of Teacher Education. Vol 36, 2012 (hal 36-57).

Facione, Peter A. (1990). Dean of the College of Arts and Sciences, and Santa Clara University. Critical Thinking: A Statement of Expert Consensus for Purpose of Educational Assessment and Instruction. The Delphi Report, California Academic Press

Goldin, G.A. (2002). Representation in Mathematical Learning and Problem Solving. Dalam L.D English (Ed). Handbook of International research in Mathematics Education (IRME). New Jersey: Lawrence Erlbaum Associates.

Hamruni. (2011). Strategi Pembelajaran Berbasis Masalah. Yogyakarta: Insan Madani.

Handayani, U. (2016). Pengembangan Modul Fisika Berbasis Problem Based Learning (PBL) Untuk Meningkatkan Keterampilan Berpikir Kritis pada Materi Usaha dan Energi di SMA/MA. Tesis. Surakarta: Universitas Sebelas Maret.

Heuvelen, Xueli, Zou. (2001). Multiple representations of work-energy processes. Americans Journal of Physics, 69 (2): 184-194

Hinrichs, B. In edited by J. Marx, P. Heron, and S. Frankli.( 2004). Physics Education. Research Conference Proceedings, Sacramento, CA, 117-120

I Putu, W. (2014). Pengembangan Lkm Multi Representasi Berbantuan Geogebra Untuk Meningkatkan Kemampuan Berpikir Kritis Mahasiswa. Jurnal Pendidikan Indonesia, 3(1)

Lovy \& Gunawan. (2008). Effects of inkuiry approach on students' generic skills in temperature concepts. The Current Issue on Research and Teaching in Science Education. Science Education Program, graduate school Indonesia University of Education (IUE). Bandung.

Meltzer. (2002). The Relationship Between Mathematics Preparation and Conceptual Learning Gains in Phisics: a Possible "Hidden Variable" in Diagnostic Pretest Score. Lowa: lowa State University. American Journal Physics, 70 (12) 1259-1268. (Online).
Mulyasa, E. (2007). Kurikulum Tingkat Satuan Pendidikan. Bandung : PT. Remaja Rosdakarya.

Mundilarto. (2013). Pendekatan Kontekstual dalam Pembelajaran Sains. PPM Terpadu SMPN 2 Mlati. Yogyakarta.

Nilam, R. (2016). Pengaruh Model Pembelajaran Inkuiri Terbimbing Berbantuan Multimedia Interaktif Terhadap Berpikir Kritis Siswa Kelas XI SMA Negeri di Bojonegoro. Jurnal Pendidikan 1 (8), 1529-1535.

Novak \& Gowin. (1985). Learning how to learn. Cambridge; Cambridge University Press.

OECD.(2014). Result: What Stuet Know and Can Do-Student Performance in Mathematic, Reading, and Science. OECD Publisihing, (1).

Ornek, F., Robinson, W. R., Haugan, M. P. (2008). What Makes Physics Difficult?. International Journal of Environment and Sciences Education, 3 (1), 30-34. Turkey: Balikesir University.

Paulinan, P. (2001). Penulisan Bahan Ajar. Jakarta: Pusat Antar Universitas dan Pengembangan Aktivitas Instruksional: Direktorat Jenderal Pendidikan Tinggi, Depdiknas.

Pratama, H. (2014). Pengembangan Modul Pembelajaran IPA Fisika SMP Kelas IX Berbasis Pendekatan Jelajah Alam Sekitar (JAS) pada Materi Gerakan Bumi dan Bulan yang Terintegrasi Budaya Jawa. Tesis. Universitas Sebelas Maret Surakarta.

Prapti,dkk. (2013). Pengembangan Perangkat Pembelajaran Berbasis masalah Pada Materi Pencernaan Makanan bervisi Pendidikan karakter. Journal of Education Research and Evaluation 2(1).

Prastowo, Andi. (2015). Panduan Kreatif Membuat Bahan Ajar Inovatif. Jogjakarta: DIVA Press.

Rosengrant, D., Van Heuvelen, A., Etkina, E.(2012). Do Students Use and Understand Free-Body Diagrams?. Physical Review Special Topics Physics EducationResearch.

Sampurno, A. (2009). Penerapan Metode Belajar Akif dalam Pembelajaran Berbasis Proyek untuk Meningkatkan Hasil Belajar. Yogyakarta : Universitas Negeri Yogyakarta. 
Samsiah Mat et al. (2012). Model of Problembased learning using systems approach. ISSN: 1877-0428, 2012 (hal 541-545).

Selcuk, G. S., Caliskan, S., \& Sahin, M. (2013). A Comparison of Achievement in Problem-based, Strategic and Traditional Learning Classes in Physics. International journal on new trends in education and their implications. 1309-6249, 4 (1) 154164.

Sirait, Judyanto. (2010). Analisis Kompetensi Multirepresentasi Siswa Pada Kinematika Gerak Lurus. Pontianak: Laporan Penelitian FKIP Untan.

Sugiyono. (2012). Metode Penelitian Kuantitatif, Kualitatif, dan $R \& D$. Bandung:Alfa Beta.

Sungkono. (2002). Pengembangan Bahan Ajar. Yogyakarta: FIP UNY.

Suparno, dkk. (2009). Reformasi pendidikan: Sebuah rekomendasi. Yogyakarta: Kanisius.

Syaifudin, A. (2011). Pengembangan Media Pembelajaran Berbasis Video Handphone Format 3gp Untuk Materi Pelajaran Fisika Kelas X Pokok Bahasan Perpindahan Kalor. Skripsi Tidak Dipublikasikan, Universitas Sebelas Maret, Surakarta.

Thiagarajan, dkk. (1974). Instructional Development for Training Teacher of Exceptional children. Bloomington Indiana: Indiana University.

TIMSS. (2011). The Third International Mathematics and Science StudyRepeat 1999. Jakarta: Pusat Pengujian Balitbang Depdiknas.

Trianto. (2011). Model-Model Pembelajaran Inovatif berorientasi Konstruktivistik Jakarta: Prestasi Pustaka.

Tze Kiong, T. et al. (2011). The Development And Evaluation of The Qualitis of Buzan Mid Mapping Module. Procedia - Social and Behavioral Sciences. Universiti Tun Hussein Onn Malaysia.

Yuvita, A. (2012). Penggunaan Bahan Ajar Fisika Dengan Pendekatan Multirepresentasi. Jurnal Pendidikan Sains, 1 (4).

Wina. (2010). Strategi Pembelajaran Berorientasi Standar Proses Pendidikan Jakarta: Kencana.(online).
Winarno. (2014). Pengembangan Modul IPA Terpadu Berbasis High Order Thinking Skill (HOTS) pada Tema Energi. Tesis. Surakarta: Universitas Sebelas Maret.

Winnie, S. (2009). Pendekatan Kombinasi Metode AHP dan Metode Cut Off Point pada Tahap Analisis Keputusan Perancangan Sistem Informasi Penjualan PT. X.

Wiyadi. (2014). Pengembangan Modul IPA Terpadu Berbasis Masalah dengan Tema Otot di SMP Negeri 2 Wonogiri Tahun Pelajaran 2013/2014. Tesis. Surakarta: Universitas Sebelas Maret 